doi https://doi.org/10.31977/grirfi.v20i2.1795

Recebido: 24/03/2020 | Aprovado: 25/05/2020

Received: 03/24/2020 | Approved: 05/25/2020

\title{
CÁLCULO E MEDIDA NA TRANSIÇÃO DE $O$ NASCIMENTO DA TRAGÉDIA PARA HUMANO, DEMASIADO HUMANO: AS PAIXÕES COMO QUESTÃo
}

\author{
Paulo Cesar Jakimiu Sabino ${ }^{1}$ \\ Universidade Federal do Paraná (UFPR) \\ (D) https://orcid.org/0000-0002-7811-672X \\ E-mail: pcjsabinol@yahoo.com.br
}

\section{RESUMO:}

O presente artigo discute as noções de cálculo e medida na obra de Nietzsche, mais especificamente na transição do seu período inicial para o período intermediário. Com isso, nossa intenção é explicitar como tais noções que soam tão pouco dionisíacas - e consequentemente, nietzschianas - podem fazer parte do conjunto da obra de Nietzsche e, mais ainda, serem essenciais para a compreensão de seu pensamento. Para que esse objetivo fosse alcançado, foram necessários os desdobramentos de conceitos como paixões e criação na obra nietzschiana, fazendo reaparecer características do conceito de apolíneo, que são praticamente despercebidos uma vez que o filósofo combina seus dois conceitos anteriores. Porém, ao fazer isso, ele compartilha conosco sua ideia de "criar a si mesmo como obra de arte". Por fim, tentamos deixar claro que quando introduzimos tais noções como cálculo e medida em sua filosofia, isso jamais o faz parecer um filósofo racionalista ou moralista, isto é, alguém que busque apresentar e estabelecer determinadas regras e normas de conduta consideradas apropriadas.

PALAVRAS-CHAVE: Criação; Apolíneo; Racionalidade; Paixões.

\section{CALCULATION AND MEASUREMENT IN TRANSITION FROM THE BIRTH OF TRAGEDY TO HUMAN, ALL TOO HUMAN: THE PASSIONS AS A QUESTION}

\begin{abstract}
:
The following article is about the notions of calculation and measurement in Nietzsche's work, to be more precise, in the transition between his first works and his intermediate one. Our intention is elucidating how these notions that sound little Dionysian - and, as consequence, little nietzschean - can be part of the entirety of the Nietzsche's work, and more, be essentials to understanding of his thought. To achieve this objective, he shares with us his idea of "to create ourselves as work of art". Lastly, we try make clear that when we introduce those notions as calculation and measurement in nietzschean philosophy, that would never make him seems a rationalist or moralist philosopher, i.e., someone that show and sets conduct rules considerate appropriate.
\end{abstract}

KEYWORDS: Creation; Apollonian; Rationality; Passions.

${ }^{1}$ Doutorando em Filosofia na Universidade Federal do Paraná (UFPR), Curitiba - PR, Brasil.

SABINO, Paulo Cesar Jakimiu. Cálculo e medida na transição de o Nascimento da tragédia para Humano, demasiado humano: as paixões como questão. Griot : Revista de Filosofia, Amargosa - BA, v.20, n.2, p.174-189, junho, 2020. 


\section{Introdução}

Quando falamos da filosofia nietzschiana é incomum que noções como cálculo e medida apareçam, pois são termos que soam pouco adequados ao filosofar dionisíaco que está associado a Nietzsche. Todavia, a proposta do texto é demonstrar que se observadas de uma perspectiva adequada essas noções são sim pertinentes, demonstrando que não cabe ao filósofo das marteladas a alcunha de "destruidor da razão". Convém, antes de dar continuidade ao texto, explorar um pouco a definição, mesmo que de maneira breve, daquilo que está sendo denominado por cálculo e medida.

O cálculo pode ser definido como um procedimento de inferência acerca de proposições que constituem um argumento a fim de extrair delas uma "conclusão" na qual seja verificável o valor de verdade da mesma. Seria, assim, um procedimento racional aplicado a determinadas possibilidades. Enquanto que a medida deve ser tomada como oposição à desmedida em Nietzsche. Podemos entendê-la como uma referência que que nos permite ponderar sobre razões, motivos, etc. impondo limites para ações e juízos. Por isso mesmo, uma ação calculada é premeditada, ajuizada e adota determinados critérios a fim de ser considerada racional, facilitando a avaliação a partir de preceitos morais ou jurídicos, por exemplo. Quando a ação é desmedida, comumente associamos ela com uma ideia que não foi suficientemente ponderada, sendo por isso considerada passional ou impulsiva e, significando que ao avaliá-la, adota-se de antemão uma postura negativa. Por essa razão, para que seja possível dar forma ao pensamento, isto é, organizá-lo e estruturá-lo, o cálculo e a medida se tornam indispensáveis.

É preciso tomar nota que por ser uma definição genérica, é preferível tratar cálculo e medida enquanto noções e não enquanto conceitos propriamente ditos. A ideia é apresentar um panorama útil para o que será tratado nas linhas a seguir.

\section{As imagens de Nietzsche}

É irresistível não iniciar o tema apresentando a figura de Nietzsche como provocadora. Da mesma maneira que suscita prazer e admiração por parte de alguns, é tachado de "irracionalista", "louco", "negador da razão"; mais poeta do que filósofo - uma vez que aparenta faltar com o rigor filosófico habitual. Por esse motivo, entre as diversas imagens que ele possui, algumas são mais realçadas em algumas interpretações. Uma imagem muito comum talvez seja a do filósofo "dinamite". Em "Por que sou um destino" de Ecce Homo, é clássica a passagem na qual se lê:

Conheço a minha sina. Um dia, meu nome será ligado à lembrança de algo tremendo de uma crise como jamais houve sobre a Terra, da mais profunda colisão de consciências, de uma decisão conjurada contra tudo o que até então foi acreditado, santificado, requerido. Eu não sou um homem, sou dinamite (NIETZSCHE, 2008a, p.102)

Ao definir a si mesmo como "dinamite", um destruidor - de ídolos, de valores -Nietzsche leva os mais desavisados a acreditar que sua filosofia é apenas destrutiva e nada tem a ver com a criação; sem considerar que destruir antecede o processo criativo. Talvez seja pela necessidade de nosso atual contexto político e cultural: diante de um conservadorismo sempre em expansão, a dinamite é mais sedutora. No entanto, Nietzsche não possui uma filosofia, não pode ser restringido a uma imagem. Quem se aventura nos seus textos sabe muito bem da pluralidade presente no seu pensamento, de maneira que seria equivocado querer limitá-lo. Sua filosofia necessita ser tomada por diferentes perspectivas. Acostumados que estamos ao filósofo dionisíaco, é difícil abandonar uma imagem tão atraente. Todavia, quando nos limitamos à essa 
imagem, a tornamos pouco precisa e não fazemos justiça ao conjunto completo de sua obra. Ocorre que isso pode soar pouco agradável, sendo uma ideia de difícil digestão para aqueles que costumam "apenas" enxergar Nietzsche como um crítico ferrenho do socratismo e da racionalidade. Nesse sentido, é oferecida aqui uma interpretação que adentra na parte criadora de sua filosofia e, assim sendo, acaba por resgatar características pouco exploradas.

Desde $O$ nascimento da tragédia é comum direcionar a leitura pelo origiástico. Um exemplo claro disso são as interpretações que se atém em demasia à figura de Dioniso, mesmo porque existem diversas páginas sobre o mesmo, diferente de Apolo que não parece gozar do mesmo reconhecimento, ainda que seja fundamental para a justificação da existência e para o nascimento da arte trágica (Cf. PAPPAS, 2014). As dificuldades em ir além do dionisíaco ocorre em relação à crítica de Nietzsche ao socratismo, porque o apolíneo está fortemente associado às características elucidadas pelas máximas de Delfos, o "conhece-te a ti mesmo" e "nada em demasia". Porém, socratismo e apolíneo não são idênticos e divergem seriamente. Para começo de conversa, enquanto uma cultura socrática busca vencer a natureza pela razão, a apolínea vai acomodá-la na beleza - em outras palavras: a segunda é uma cultura artística.

Todavia, torna-se mister admitir que características apolíneas, como o cálculo e a medida, podem facilmente ser encontradas no socratismo, e podem servir muito bem ao pensamento lógico-conceitual, característico da filosofia ocidental tão criticada pelo filósofo. Então, para expor a questão sem embaraços é preciso realizar um movimento que explore as qualidades apolíneas e demonstre que estas jamais foram abandonadas completamente por Nietzsche. $O$ que justifica a afirmação de que a sua filosofia criativa acomode o cálculo e a medida. Para a abordagem do tema o foco será, principalmente, as obras de dois períodos, $O$ nascimento da tragédia e Humano, demasiado humano - livro dividido em dois volumes -, a fim de tentar sustentar a proposta dentro de uma determinada economia de argumentos.

\section{O Nascimento da Tragédia: por que o apolíneo não deixa de brilhar?}

É no livro de estreia de Nietzsche que o apolíneo ganha mais destaque em sua filosofia ${ }^{2}$. No entanto, não é este o elemento inovador, uma das grandes novidades de $O$ Nascimento da Tragédia é a presença do dionisíaco ${ }^{3}$, tendo em vista que desde muito cedo era comum na Alemanha um certo sentimento nostálgico pela Grécia antiga, que foi iniciado com Winckelmann e sua famigerada ideia do "imitar os antigos para sermos inimitáveis". Entretanto, se o apolíneo não é uma novidade, é inegável que cumpra função fundamental, sem a qual a arte trágica não seria possível.

Dividida em três partes - (i) o nascimento da arte trágica; (ii) a morte da arte trágica pelo socratismo; (iii) o renascimento do espírito trágico na Alemanha mediante a música de Wagner - a obra é mais do que uma proposta estética, porque traz uma proposta pedagógica que ao mesmo tempo se configura como uma crítica ao espírito moderno alemão. Nesse sentido, afirma Schacht que:

O nascimento da tragédia para Nietzsche foi um evento de grande importância; esse evento não envolve apenas a aparição de uma nova forma de arte, de modo que se abre outro capítulo no desenvolvimento da arte. Isso torna possível, posteriormente, uma transformação da vida humana, a qual ele entende ter sido, de longe, um momento muito mais importante do que geralmente é reconhecido (SCHACHT,2002, p.497).

\footnotetext{
2Apenas no final de seu percurso intelectual, como em Crepúsculo dos Ídolos, seção §10, "Incursões de um extemporâneo", Nietzsche retoma o apolíneo e com significados distintos.

3 Cf. NIETZSCHE, 2008, p.60. No próprio Ecce Homo Nietzsche reconhece o dionisíaco como uma das novidades, a outra teria sido o reconhecimento do fenômeno do socratismo.
} 
Com alguma precaução, é possível afirmar que nesse livro ele realiza a tarefa que viria a tomar conta de seus escritos tardios, isto é, a realização de um diagnóstico da cultura. O que faz nesse momento, mas não o faz posteriormente, é buscar uma "cura": Wagner. Nietzsche acreditava que pela arte trágica era possível dar fim ao declínio cultural alemão, e a música wagneriana se apresentava como uma correspondente da força existente na tragédia grega. Para a realização de tal tarefa, ele introduz na sua obra o que chama de "pulsões estéticas da natureza", o apolíneo e o dionisíaco, que são formados a partir das noções kantianas de "fenômeno" e "coisa-em-si" e principalmente "representação" e "vontade" - tomadas de empréstimo de seu mestre, Schopenhauer. Na seção 1 do livro, Nietzsche trata de elucidar as pulsões como fenômenos artísticos naturais, isto é, sem mediação do ser humano. Sua intenção é explicar como a cultura grega era dominada pelo impulso apolíneo ao mesmo tempo em que estava às voltas com o impulso dionisíaco, que imperava nos povos bárbaros que rondavam a Grécia.

Os gregos, descritos como membros de uma cultura equilibrada, harmônica e dominadas pelas leis de medida e contenção tanto na esfera da ética como na estética, tinha sua organização social ameaçada pelo dionisíaco. Enquanto deus das artes plásticas, Apolo caracteriza a pulsão que dá forma, e, por isso mesmo, será qualificado a partir de duas concepções também emprestadas de Schopenhauer: o principium individuationis e o "Véu de Maia". O principium caracteriza o processo de dar forma de Apolo, em que este delimita os indivíduos e as coisas entre si, estabelecendo as fronteiras:

\footnotetext{
Apolo, deus da arte escultórica, senhor do mundo do sonho e da "bela aparência", reina supremo no mundo da forma, demarcando com firmeza as fronteiras entre os indivíduos e entre estes o mundo que os cerca, de modo a lhes permitir existir com a segurança de serem únicos e unos, de não se perderem em meio à diversidade e ao caos, de não mergulharem no indeterminado e de não deixarem dilacerar pela violência das paixões mais selvagens (RODRIGUES, 2003, p.25).
}

Em razão disso, o apolíneo engendra assim o mundo onírico e o mundo dos deuses olímpicos que protegerá o grego dos ritos dionisíacos bárbaros que formavam oposição às características mais essenciais da pólis helênica, pois pelo impulso dionisíaco o ser humano é tomado por um sentimento de êxtase, de desmedida e embriaguez. Porém, o mais fundamental é a proteção dos gregos contra os horrores da existência que viriam a descobrir pela sabedoria dionisíaca - sabedoria esta que é expressa pelas palavras de Sileno, conforme a narrativa descrita por Nietzsche: o Rei Midas persegue o companheiro de Dioniso e quando consegue apanhá-lo, pergunta qual é a melhor coisa e a mais desejável ao homem. A resposta é assombrosa:

Estirpe miserável e efêmera, filhos do acaso e do tormento.! Por que me obrigas a dizerte o que seria para ti mais salutar não ouvir? O melhor de tudo é para ti inteiramente inatingível: não ter nascido, não ser, nada ser. Depois disso, porém, o melhor para ti é logo morrer (NIETZSCHE, 2005, p.36)

Essa sabedoria anuncia a existência desnudada na qual o absurdo tomaria conta do grego fazendo com que sua existência perdesse o sentido. Sem sua capacidade de equilibro o grego fica à mercê de um mundo desprovido de significado. Logo, a resistência da cultura apolínea ao dionisíaco não se dá apenas em razão da "corrupção moral”. Em maior parte, o grego resistia para desviar o olhar de uma perspectiva de existência que era pouco agradável. $O$ escudo de 
Apolo era necessário porque se configurava como uma proteção que constitui um mundo imagético - mesmo que ilusório - tornando possível viver; tornando a vida "justificada"4:

É, portanto, ao ser tocado pelo poder imagético apolíneo que o homem aprende a extrair das aparências o significado para seu viver; [...] Apolo representa, para Nietzsche, uma espécie de força ou, como ele mesmo chama, "potência artística da natureza", que criaria "mundos" povoados de imagens, vivesse um anteparo à dolorosa visão do fundo mais íntimo do mundo (RODRIGUES, 203, p.26).

Explicando de maneira concisa: diante da existência dolorosa o grego soube se proteger na beleza. Essa característica, inclusive, é uma das qualidades que Nietzsche admirava nos gregos, sua "excitável aptidão ao sofrimento" (NIETZSCHE, 2005, p.38). Eles não negavam ou prometiam algo em troca do sofrer, simplesmente não estão orientados a entender que sofrer seria algo necessariamente negativo. Tendo em vista a sensibilidade grega ao sofrimento, seus modos de apreciação da existência são exaltados na filosofia nietzschiana a fim de resgatar esse interesse pela vida que aqui temos.

Contudo, era inevitável que Dioniso, enquanto uma pulsão estética, destruísse de tempos em tempos o véu de Maia, interrompendo a proteção apolínea e demonstrando sua insuficiência. O dionisíaco, associado àquela sensação de êxtase e desmedida, é a pulsão que rompe com o principium inviduationis unindo novamente o ser humano à natureza:

Agora o escravo é homem livre, agora se rompem todas as rígidas e hostis delimitações que a necessidade, a arbitrariedade ou a "moda impudente" estabeleceram entre os homens. Agora, graças ao evangelho da harmonia universal, cada qual se sente não só unificado, conciliado, fundido com o seu próximo, mas um só, como se o véu de Maia tivesse sido rasgado e, reduzido a tidas, esvoaçasse diante do misterioso Uno-primordial (NIETZSCHE, 2005, p.31)

Esse substrato de conhecimento que obrigou os gregos a protegerem-se na beleza se manifesta imperiosamente. Rompe com a camada protetora, uma vez que ela é superficial. É tentador entender esse conflito das pulsões como o antagonismo entre civilização e barbárie sendo esse estado de natureza mais poderoso contra a fragilidade das normas civilizatórias. Só que é preciso lembrar também do alerta do próprio Nietzsche: há um abismo que separa os gregos dionisíacos dos bárbaros dionisíacos (cf. NIETZSCHE, 2005, p.33). De modo que seu interesse reside no dionisíaco que entrava em contato com a cultura apolínea grega e os obrigava a sair da proteção de Apolo. Isso porque foi quando o dionisíaco entrou em contato com essa cultura que, em conjunto com o apolíneo, originou um tipo específico de arte. A selvageria dos impulsos e a noção de ordem daquela civilização engendraram, assim, a tragédia tal como $\operatorname{conhecemos}^{5}$.A destruição do escudo não a destruição da pulsão antagonista ou a declaração de guerra, mas a necessidade de uma trégua. E por esse motivo esclarece o filósofo:

Mais perigosa e até impossível tornou-se a resistência, quanto, o fim, das raízes mais profundas do helenismo começaram a irromper impulsos parecidos: agora a ação do deus délfico restringiu-se a tirar das mãos de seu poderoso oponente as armas destruidoras, mediante uma reconciliação concluída no devido tempo. Essa reconciliação é o movimento mais importante na história do culto grego: para onde quer que se olhe, são visíveis as revoluções causadas por este acontecimento. Era a reconciliação de dois adversários, com a rigorosa determinação de respeitar doravante as respectivas linhas

\footnotetext{
${ }^{4}$ É celebre uma das afirmações do livro, segundo a qual "só como fenômeno estético podem a existência e o mundo justificar-se eternamente" (NIETZSCHE, 2005, p.47).

5 Embora indique a tragédia era, originalmente, apenas música. Nietzsche aborda com maior intensidade a tragédia ática enquanto uma forma de arte desenvolvida dentro da cultura apolínea.
} 
fronteiriças e com o periódico envio mútuo de presentes honoríficos: no fundo, o abismo não fora transposto por ponte nenhuma. Quando vemos, porém, como, sob a pressão deste pacto de paz, a potência dionisíaca se manifestou, reconhecemos agora nas orgias dionisíacas dos gregos, em comparação com as Sáceas babilônicas e sua retrogradação do homem ao tigre e ao macaco, o significado das festas de redenção universal e dos dias de transfiguração. Só com elas alcança a natureza o júbilo artístico, só com elas tornasse o rompimento do principium individuationis um fenômeno artístico. (NIETZSCHE, 2005 , p.33-4).

As Sáceas bárbaras, apesar de motivadas por uma pulsão que seria estética, não configura ainda um fenômeno artístico. Isso ocorre apenas em união com o apolíneo, pois é esse o princípio criador e que dá forma ao caldeirão turbulento de instintos e pulsões apresentados pelo dionisíaco. A barbárie e hostilidade daquele universo no qual impera a desmedida torna-se um elemento fundamental para o grego, sendo que seria mérito dos gregos conseguir unir essas forças estranhas e antagônicas. Nasce assim uma metafísica de artista, na qual a essência do mundo, a vontade, é apresentada pela aparência, a representação. A tragédia grega apresenta ao ser humano os elementos mais fundamentais da vida - elementos que expõem o absurdo da existência, mas que quando mediados pelo apolíneo, permitem a vida ser vivida. Aquele conhecimento, antes impossível, torna-se agora possível de intelecção - expondo o caráter pedagógico da tragédia que ensina a viver, "vivendo".

Nessa perspectiva, nota-se que foi o princípio apolíneo com suas noções de medida e cálculo que permitiram justificar a existência, porque mediante tais noções foi possível dar forma àquela força imperiosa de Dioniso. Sem ele, a tragédia não seria possível. Logo, é inapropriado associar essa cultura apolínea com uma cultura socrática, pois a primeira é artística e soube acomodar o dionisíaco na sua existência, diferente da cultura socrática, que buscou controla-lo mediante a racionalidade ou até mesmo negá-lo - sendo a responsável pela morte da arte trágica. Diferente da cultura socrática, a apolínea não aplica as noções de cálculo e medida a conceitos, e sim a imagens, tornando-as claras e belas, permitindo as paixões tomarem forma - a concepção é estritamente artística, os usos são completamente diferentes:

Da mesma forma que havia sido capaz de impor-se como princípio da medida e da bela aparência e, durante longos tempos, "enganar" o grego de que valeria a pena continuar querendo viver, de que fazia sentido crer na vida, a "vontade helênica", revelando uma "sabedoria" rara, pôde, mais uma vez, manipulando as forças apolíneas da aparência, ir ao encontro do perigo dionisíaco, acolhendo-o, em vez de resistir-lhe, impondo-lhe os limites dentro dos quais ele poderia se expressar (NIETZSCHE, 2005, p.46)

As forças dionisíacas podem ser expressadas desde que recebam a forma teatral da tragédia, na qual a vida é encenada. Os gregos possuíam um meio de exteriorizar as paixões que antes não encontravam saída na civilização. Claro que natureza e civilização são opostos, e isso significa que Apolo e Dioniso são forças estranhas e um apresenta resistência ao outro, já que os rituais dionisíacos são muito diferentes dos rituais olimpianos - a diferença foi a possibilidade de um conviver com o outro. O grego, porém, estava alerta dos perigos de negar ao deus seu devido espaço - como nos mostra Eurípides em As bacantes: Penteu, representante do tipo civilizado, é destruído pelas bacantes em estado de êxtase, entre elas, sua própria mãe. Cientes desse perigo, a postura do grego precisa ser destacada: ele impõe forma às forças arrasadoras da natureza, mas não de forma sublimada, isto é, sem que energias precisassem de redirecionamento e conseguissem atingir sua meta. O teatro é isso: natureza no meio da civilização, estímulo aos impulsos que lembram o ser humano de que a razão não é autossuficiente.

Logo, Apolo não reprime Dioniso, mas impõe a ele um estilo. Podemos afirmar, então, que Nietzsche é um filósofo do cálculo e da medida? Sim, desde que possamos compreender paixões como questão. Griot : Revista de Filosofia, Amargosa - BA, v.20, n.2, p.174-189, junho, 2020. 
melhor esse aspecto, uma vez que ele se considera discípulo de Dioniso - e isso faz Apolo, ao que tudo indica, desaparecer de seus textos. Como então ele é um filósofo que preza por características apolíneas? É preciso lembrar ao leitor que após o livro de estreia, na obra que pode ser considerada um momento de ruptura no seu percurso intelectual, Humano, demasiado humano, a arte ganha um tratamento diferenciado, na qual Nietzsche admira mais a ciência e dá um tratamento aparentemente hostil à esfera estética? Para elucidar com maior clareza esse ponto, podemos nos valer dos argumentos de Gerard Lebrun em “Quem era Dioniso?".

\section{Uma despedida para Apolo?}

No artigo "Quem era Dioniso" Gerard Lebrun defende que durante o percurso intelectual de Nietzsche ocorre uma mudança no conceito de Dioniso, em razão de uma nova orientação para sua filosofia. Conforme aponta no seu texto, embora seja possível argumentar a favor da hipótese de que em $O$ nascimento da tragédia há o triunfo de Apolo sobre Dioniso, é igualmente plausível que no decorrer de sua filosofia a vitória seja do deus do vinho (Cf. LEBRUN, 2005, p.361).

De início, não é problemático explicar o porquê do conceito Apolo/apolíneo ser abandonado. Ora, enquanto escrevia seu livro de estreia ele ainda estava preso ao pensamento metafísico que se configurava por meio de dicotomias tais como: essência $\mathrm{x}$ aparência; verdade $\mathrm{x}$ mentira; coisa-em-si x fenômeno; vontade x representação. Os conceitos Apolo e Dioniso apareciam identificados com tais dicotomias, porém, ao negar a existência de um "além-mundo" ou de uma esfera superior a realidade e de uma verdade "essencial", caem por terra também a dicotomia representada pelas divindades gregas. Os textos que antecedem. Humano, demasiado humano podem ser considerados livros ainda impregnados de uma metafísica de artista. De modo que com isso a própria noção de criação e arte passará a ser reformulada e corrigida, pois " objetivo da Arte não pode mais ser o de afastar nosso olhar do 'ser verdadeiro'. Ser autenticamente Künstler não será mais criar imagens de sonho, mas, ao contrário, afirmar ( $J a$ sagen) a realidade da qual o apolinismo ocultava o aspecto terrível" (Ibidem, p.362).

Para Lebrun, após essa mudança de orientação, isto é, do abandono da metafísica e das dicotomias, as características antes exclusivas de Apolo são introduzidas no conceito de Dioniso. Daí que Lebrun afirma: "o artista autêntico não tem de escolher Apolo contra Dioniso, desde que considere este último como "deus bifrons", deus do delírio, mas também da medida" (Ibidem, p.362). À condição de acatarmos essa tese, cálculo e medida não serão mais noções estranhas a Dioniso, pelo contrário, fazem parte dele. Com isso, uma filosofia dionisíaca ou mesmo uma arte dionisíaca não é mais a arte da desmedida, sendo, na verdade, esse tipo de arte um objeto de crítica em Humano, já que o domínio dos afetos e a necessidade de coerção será uma qualidade que falta aos modernos. Algo que se comprova através de sua nítida críticaao aspecto "desordeiro" de seu tempo, e também pela adesão ao classicismo justamente como estratégia para se opor ao romantismo metafísico que preza e enaltece a "desmedida" e a criação "genial/divina". Por esse motivo, Lebrun sente a necessidade de alertar: a saída de Apolo não indica complacência com o orgiástico e, menos ainda, autoriza a alcunha de "destruidor da razão". A crítica à racionalidade possui um ponto bem específico: a divisão entre corpo e razão que ainda resultou num arranjo hierárquico inapropriado entre essas duas esferas.

O conceito de Dioniso precisava ser reformulado uma vez que ele estava configurado a partir de noções metafísicas. Ele sustentava ainda a oposição entre poiésis e tekhne - oposição que já aparece no Íon de Platão, diálogo no qual temos a ideia de que o artista cria em razão de um entusiasmo. No que concerne à arte, Nietzsche buscou desmistificar que a criação artística é 
fruto de inspiração ou de uma capacidade que apenas um ser divino, o gênio, poderia possuir ${ }^{6}$. Nietzsche acredita que isso é depreciar o verdadeiro processo de criação que, diferentemente de um ato miraculoso, é resultado de um trabalho paciente e cauteloso, que deve ser trabalhado no cotidiano e com cara atenção aos detalhes. Por trás de um grande "milagre" artístico, há um enorme processo de criação que não foi levado em conta ${ }^{7}$; e a partir dessa ideia Dioniso deixa de ser a parte genial que inspira o lado apolíneo a criar. Ele é o próprio criador. Não aparece mais identificado com a vontade informe de Schopenhauer, mas com a capacidade de dar forma, estilizar.

No texto, Lebrun não só elucida o desaparecimento de Apolo nos textos de Nietzsche, ele também argumenta em favor da vitória de Dioniso contra Apolo. Contrariar essa tese é difícil e nem é intento do texto aqui exposto. Contudo, mesmo sendo, posteriormente, pouco abordado na sua filosofia, é desastroso ignorá-lo. As características criativas de Apolo serão fundamentais para a posterioridade do pensamento filosófico nietzschiano. Voltar às suas qualidades é essencial para compreender o porquê da filosofia de Nietzsche nunca ter sido estritamente orgiástica, de maneira que tornasse o indivíduo "escravo das paixões". O que não é nenhum problema e nem mesmo a desqualifica. A necessidade de medida e cálculo é a exigência de um ato disciplinador exercido sobre si mesmo; por isso é fundamental perceber a real intenção de seu pensamento: não se trata de "destruir" a civilização e a repressão que a acompanha, mas buscar meios de vencê-la exteriorizando os nossos afetos. Agora, a partir dessa orientação pelo apolíneo, é possível indicar que o mal-estar gerado pela vida civilizada não advém de sua obscena exigência de excluir as qualidades impudicas e pouco sociais do ser humano, mas sim de nossa impossibilidade de resistir ao processo civilizatório de uma maneira menos negativa.

Para levar adiante a discussão, é interessante recuperar duas ideias do artigo de Lebrun. Segundo o autor, Nietzsche não teria avaliado corretamente um critério fundamental em $O$ nascimento da tragédia, tornando sua noção de Dioniso equivocada. Esse critério era a linha de separação entre afirmação da vida contra negação deste; saúde contra morbidez (Ibidem, p.368). Ora, mas o que isso quer dizer? O que seria, exatamente, afirmar a vida e o grande dizer Sim que seria elemento privilegiado e talvez o principal leitmotiv de sua filosofia tardia? A resposta pode ser melhor formulada através dos textos de Humano. Se no seu primeiro livro o fundamental na criação apolínea era a "justificação da existência", agora, após o remanejamento dos argumentos e correção dos conceitos, a criação dionisíaca se torna "expansão da existência"; afirmar é criar. Essa criação necessita da coerção, e que nos leva à segunda ideia do artigo: de que coerção não é apenas externa - escravidão - mas é também interna (Cf. Ibidem, 373). Um autodomínio permite criar a si mesmo como obra de arte, e isso possibilitará pensar essa disciplina de si como uma tarefa distinta da de Sócrates, por exemplo. Afinal de contas, esse autodomínio poderia muito bem ser relacionado à filosofia socrática. Acontece que o homem não exercerá essa capacidade mediante sua racionalidade, mas mediante o corpo.

Com Humano, Nietzsche procura outra finalidade para a arte, outros meios de aproveitála. De uma nova ótica, irá atacar a ideia de que a arte seja expressão de verdades, preferindo torná-la um expediente em favor da expansão da existência e para modelar as paixões. Assim não fica limitada à esfera estética, mas é estendida a outras esferas da existência humana.

\footnotetext{
${ }^{6}$ Será fundamental, depois, para autorizar dizer que a vida é obra de arte. Caso a criação, o tornar algo arte, fosse qualidade de um ser especial, nossas existências só poderiam ser "criadas" - e consequentemente dominadas - por outro e não por nós mesmos, jamais seriamos senhores de si.

7 No aforismo 155 "A crença na inspiração" de Humano, demasiado humano, Nietzsche ataca a ideia de que um trabalho grandioso seja fruto de um instante repentino intitulado "inspiração". Para ele, todo o criar grandioso é paciente, por isso afirma: "Todos os grandes foram grandes trabalhadores, incansáveis não apenas no inventar, mas também no rejeitar, eleger, remodelar e ordenar" (NIETZSCHE, 2004, p.119-20).
} 


\title{
Humano, demasiado humano: um novo caminho para o pensamento estético
}

Humano, demasiado humano pode ser considerado, como dito antes, a obra que marca um momento de ruptura no pensamento do filósofo. Para defender tal posição podemos argumentar dois pontos: (i) há no livro uma clara tentativa de superação do pensamento metafísico; (ii) o romantismo é abandonado. O primeiro ponto permite uma justificativa sem muitas complicações. As obras do assim chamado "período intermediário" são aquelas na qual há um tom bastante positivo quanto as ciências naturais, uma vez que Nietzsche enxergava nelas, em parceria com o filosofar histórico, um instrumento para combater a metafísica. Isso é nítido no aforismo que abre o livro "química dos conceitos e sentimentos":

\begin{abstract}
Em quase todos os pontos, os problemas filosóficos são novamente formulados tal como dois mil anos atrás: como pode algo se originar do seu oposto, por exemplo, o racional do irracional, o sensível do morto, o lógico do ilógico, a contemplação desinteressada do desejo cobiçoso, a vida para o próximo do egoísmo, a verdade dos erros? Até o momento, a filosofia metafísica superou essa dificuldade negando a gênese de um a partir do outro, e supondo para as coisas de mais alto valor uma origem miraculosa, diretamente do âmago e da essência da "coisa em si". Já a filosofia histórica, que não se pode mais conceber como distinta da ciência natural, o mais novo dos métodos filosóficos, constatou, em certos casos (e provavelmente chegará ao mesmo resultado em todos eles), que não há opostos, salvo no exagero habitual da concepção popular ou metafísica, e que na base dessa contraposição está um erro da razão: conforme sua explicação, a rigor não existe ação altruísta nem contemplação totalmente desinteressada; ambas são apenas sublimações, em que o elemento básico parece ter se volatilizado e somente se revela à observação mais aguda (NIETZSCHE, 2004, p.15)
\end{abstract}

Através das ciências e do filosofar histórico, pretende desconstruir as superstições metafísicas, tais como a ideia de uma origem, a essência e a imutabilidade das coisas. Explica-se, assim, o título do livro: seja o que for que existe no mundo e em nossa existência, elas são produções totalmente humanas - isso se aplica à moral, ao conhecimento e à arte. Por isso a mudança de tom em relação às artes, como se fosse uma mudança de gosto ou de orientação que representava o abandono da esfera artística. Mas muito contrariamente, ele quer ampliar seu valor, hostilizando as artes que são complacentes com a metafísica e cujo principal objetivo seria o desvelar de uma verdade possível apenas à arte.

Agora, o mais complexo é sua crítica ao romantismo. Mesmo que hajam boas razões para justificar tal perspectiva, muitas dificuldades se impõe. No "Prólogo" escrito em 1886 ao segundo volume do livro, Nietzsche menciona que a obra se tratava de uma continuidade daquele que foi sua "cura espiritual", seu "tratamento anti-romântico" (Cf. NIETZSCHE, 2008 b, p.09). A dificuldade se impõe em saber qual é esse romantismo criticado, mesmo que seja evidente sua estratégica simpatia ao classicismo para combater o romantismo. $O$ próprio filósofo já problematizou sua obra. Em determinadas cartas (como a carta a Overbeck de 13 de julho de 1885) e em Crepúsculo dos Ídolos "O que devo os antigos", ele acaba sendo mais tolerante com seus textos juvenis, e ressalta que neles haveria, também, um anti-romantismo (Cf. NASSER, 2009 , p.32). Ademais, é difícil precisar quais seriam os românticos que Nietzsche tem em mente quando critica o romantismo, pois ele menciona alguns autores como August Schlegel, Novalis e Hölderin. Diante de tais dificuldades que exigiriam obter informações que não foram oferecidas a nós por Nietzsche, é preferível analisar os detalhes que ele deixa em aberto. $\mathrm{O}$ aforismo 217 de "O andarilho e sua sombra" pode tornar as coisas um pouco mais claras. Nele Nietzsche caracteriza o clássico como expressão de força e o romantismo de fraqueza, retomando a 
argumentação de Goethe quando apresenta o classicismo em oposição ao romantismo ${ }^{8}$. Entendendo-os como força e fraqueza, nosso filósofo sugere algo que será muito comum em suas reflexões: a ideia de que as produções humanas são sempre sintomas de condições do corpo: saúde ou doença, força ou fraqueza. De maneira que podemos entender classicismo e romantismo como "sintomas psicofisiológicos". A transposição dos conceitos de classicismo e romantismo para a esfera da psicofisiologia não exclui suas características, isto é, o clássico como um modelo de ordenação racional e perfeito equilíbrio, harmônico, que cultua as regras e o romantismo como uma esfera na qual impera o anticientificismo, a subjetividade e o estimulo na expressão das emoções. Entretanto, torna os conceitos suscetíveis a interpretações mais flexíveis, uma vez que não ficam restritos a uma única perspectiva.

É preciso ressaltar que mesmo aderindo ao romantismo no início, o pensamento acerca da exteriorização das paixões em $O$ nascimento da tragédia não é totalmente ingênuo, pois Nietzsche reconhece que esse processo ocorre em um espaço planejado e formalizado. Porém essa interpretação pode ter um tom romântico e ingênuo, quando se acredita que é expressão de força justamente aquilo que representa a fraqueza - a desmedida. Vale salientar ainda que o próprio Dioniso é retratado naquele livro dentro dos moldes tradicionais do romantismo (Cf. RODRIGUES, 2007)9.

Para ser breve: sustenta-se que durante seus escritos de juventude havia uma tendência ao romantismo em Nietzsche que o impediu de pensar um processo pedagógico das paixões de uma forma mais criteriosa, já que sua intenção era demonstrar a essência da vida mediante a arte trágica. Logo, quando escreve Humano e reflete a partir do classicismo, a arte muda de tarefa e até mesmo a tragédia e a música deixam de ocupar um espaço privilegiado. Nietzsche combate assim uma arte "fraca" que não permite o fortalecimento do indivíduo. Deixa de lado o ar nacionalista e ocupa-se menos com a formação (Bildung) da cultura alemã em geral, atendose ao processo de criação de nós mesmos, no qual poderia dar forma às paixões e aos aspectos mais difíceis da nossa existência sem recorrer a qualquer esfera metafísica. Nietzsche busca recuperar o que na arte é mais saudável e estimulante: seu processo criativo.

Os três últimos aforismos da seção que investiga a arte em Humano I são orientados pela superação da metafísica e abertura de um novo "tipo" de arte. Aqui apresenta-se os mesmos de maneira sequencial chamando a atenção para alguns pontos específicos. No primeiro deles, 221 "A revolução na poesia", uma passagem muito interessante já demonstra a necessidade de coerção, medida e cálculo. Em clara crítica aos seus contemporâneos, elogia os dramaturgos franceses pela coerção que impuseram a si com respeito à unidade de ação, ao tempo e ao lugar, construindo assim um estilo - dando forma à sua obra. Elogia ainda Voltaire por sua "moderação grega", uma característica que em $O$ nascimento da tragédia reside na cultura helênica apolínea. Só que o trecho mais curioso desse aforismo é a distinção que Nietzsche faz entre as "rédeas da lógica" e as da "medida artística":

Desde então o espírito moderno, com sua inquietude, com seu ódio à medida e ao limite, passou a dominar em todos os campos, primeiro desencadeado pela febre da revolução e depois novamente impondo-se rédeas, quando assaltado por medo e horror de si mesmo - mas as rédeas da lógica, não mais da medida artística (NIETZSCHE, 2004, p.149, grifo nosso).

Não foi a única vez que o filósofo se posicionou criticamente em relação à lógica. É discutível se o termo "lógica" possui uma acepção mais ampla ou uma mais restrita, como uma

\footnotetext{
8 "chamo clássico ao saudável e romântico ao que é doentio" (ECKERMANN apud NASSER 2009, p.313).

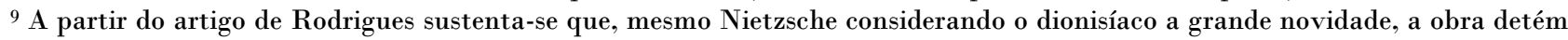
certas características de um Dioniso tradicional do romantismo alemão representado por Goethe, Novalis, Herder e Hölderin.
} 
disciplina filosófica, por exemplo. $\mathrm{O}$ tema já foi abordado por alguns comentadores ${ }^{10}$, mas para evitar excessos, a investigação fica restrita aqui a uma questão especial. Um dos pontos questionáveis para o filósofo é a função instrumental da lógica, que busca oferecer coerência ao argumento e, assim, torná-lo plausível. Longe de querer defender os argumentos incoerentes ou irracionais, a crítica que se estabelece sem maiores dificuldades para se compreender é: a lógica não é desnecessária, mas insuficiente, uma vez que o indivíduo dotado de pulsões e paixões não é necessariamente convencido pela coesão do argumento - não há uma preocupação muito clara com a educação do páthos de cada um, apenas espera-se que ele supere seu estado de ânimo e possa, assim, compreender o argumento a fim de analisá-lo com objetividade e clareza para ajuizar sobre seu valor de verdade. $\mathrm{O}$ mais comum quando um argumento está em desacordo com a verdade é considerar um erro do intelecto, que precisaria ser reeducado, ou seja, o foco da educação não é o corpo, quando na verdade um não pode estar dissociado do outro. Pode-se entender que as noções de medida da lógica são aplicáveis apenas aos argumentos e proposições, enquanto a artística aplica os mesmos as paixões e aos sentimentos, buscando uma educação da sensibilidade humana - elas não servem para garantir coesão argumentativa, mas a forma dos sentimentos, pois o artista, na sua obra, não expressa um "conceito" e sim uma vivência. Isso, claro, não é uma definição geral de arte, mas é possível defender que na sua conversão ao classicismo, interessa mais a Nietzsche o efeito da obra do que um suposto conhecimento que a mesma poderia oferecer - seja conceitual ou sobre a essência.

É justamente afastando-se da necessidade de "verdade" na obra de arte que ele pode pensar as noções de medida no seu aspecto formal a fim de dar força à expressão de um sentimento. Anteriormente, a vida necessitava de justificava quando sua essência/verdade era exposta pela sabedoria dionisíaca. Agora não haverá um sentido em si para a própria vida, e, consequentemente, a ideia de que a arte poderia desvelar a verdade é abandonada. $\mathrm{O}$ elogio à coerção é um elogio ao fazer artístico que se constrói de maneira paciente e demorada. Logo, não é a razão ou uma esfera externa que coage, mas o própria indivíduo mediante uma experiência constante de si mesmo. A busca por um estilo é um processo experimental que deve ser aplicado constantemente para chegar até a excelência - se a música de Beethoven exigiu inúmeras tentativas de composição, a mesma coisa acontece para a busca de um estilo às paixões.

No aforismo 222, Nietzsche se pergunta o que restaria da arte após destituirmos seus aspectos metafísicos. Um desses aspectos é justamente a ideia de que a arte expressa um mundo melhor e verdadeiro. $O$ filósofo se dá conta que uma das funções mais importantes da obra de arte é a apreciação da existência, mas quando a arte se desvincula da vida, ela se afasta perdendo a potência de estímulo à vida - sem a necessidade criar uma máscara para isso. Então, se é correto afirmar que das características apolíneas, a capacidade de dar forma permanece, o mesmo não se pode dizer do "véu de Maia".

Por isso mesmo a frase de o nascimento da tragédia ${ }^{11}$ entra em contraste com àquela retirada de $O$ noiva de Goethe: "seja como for, é boa a vida". De agora em diante, "justificar" ou "tornar suportável" não é mais papel da arte, porque isso significaria dizer que a vida é dolorosa de maneira insuportável sem a arte. A ideia não é fazer a vida "parecer" boa, encobrir seus terrores, é, isto sim, torná-la desejável em todos os seus aspectos. Permanece a ideia de que a arte permite recuperar o interesse pela vida, isso aconteceria, agora, de maneira muito distinta, não mais através de uma justificativa, e sim de uma afirmação.

Conforme aponta Nietzsche no fim do aforismo, mesmo que a arte desaparecesse e a ela renunciássemos, seria impossível renunciar ao que ela semeou. Tendo intensificado esse desejo pela existência, a necessidade de se alegrar continuaria sendo uma exigência. E o aforismo

${ }^{10}$ Sobre essa discussão, cf. HALES, 1996.

11 "Só como fenômeno estético podem a existência e o mundo justificar-se eternamente" (NIETZSCHE, 2005, p.47). 
termina misterioso: "o homem científico é a continuação ${ }^{12}$ do homem artístico". Estaria, assim, delegando essa tarefa à ciência? Se antes o artista nos permitia viver, isso será, de agora em diante, tarefa do cientista? $O$ último aforismo indica que sim, pois sugere que um dia nós enxergaremos o artista com certa nostalgia "o que há de melhor em nós é talvez legado de sentimentos de outros tempos, os quais já não alcançamos por via direta" (Ibidem, p.153) - a arte tornar-se-á uma doce lembrança da juventude da humanidade. Ora, mesmo que o aforismo indique uma resposta negativa para a questão da arte, não podemos negar um certo gosto e admiração pela capacidade que a arte teria em nos fazer amar a vida. Porém, é possível apreciar o último aforismo de modo salutar à esfera estética. O título é bastante sugestivo: “crepúsculo da arte". O termo "crepúsculo" parece bem apropriado: o que é esse fenômeno natural, senão um momento de transição; do dia para a noite, de dois fenômenos distintos - a passagem de um para o outro misturando as cores claras do dia com as cores escuras da noite. Parece interessante essa postura perante a arte: em um determinado momento a arte está desaparecendo em razão do novo período antimetafísico inaugurado pela ciência. A arte tende a desaparecer, mas ela se mescla e algo novo surgirá. E nessa junção entre arte e ciência, a primeira não será abandonada. Na verdade, será expandida. A arte será a estrutura para as demais atividades da vida, inclusive para a ciência. O homem científico não é a superação do homem artístico, é seu desenvolvimento, logo, guarda o que o antecessor lhe ensinou.

Segundo Richard Schacht, após o período inicial de Nietzsche a arte muda de função:

E sua avaliação madura sobre isso [o débito que possuímos com a arte] também é diferente daquela que ele inicialmente forneceu em $O$ nascimento da tragédia. Poderíamos colocar essa diferença tardia nos seguintes termos; a ênfase muda da função que arte possuí enquanto sustentação da vida para as contribuições que ela fornece para a expansão [enhancement] da vida. (SCHACHT, 2002, p.523).

A arte expande a existência. Como ela faz isso? Não é produzindo obras. Como dito, há uma nova arte emergindo nesse crepúsculo. A arte, para que pudesse ser colocada como centro de várias atividades humanas, precisou ser reinventada. Para que possamos compreender qual é essa arte, é vital a leitura do aforismo 174 “contra a arte das obras de arte", presente no segundo volume de Humano, demasiado humano:

A arte deve, sobretudo e principalmente, embelezar a vida, ou seja, tornar a nós mesmos suportáveis e, se possível, agradáveis para os outros: com essa tarefa diante de si, ela nos modera e nos contém, cria formas de trato, vincula os não-educados a leis de decoro, limpeza, cortesia, do falar e calar no momento certo. Depois a arte deve ocultar ou reinterpretar tudo que é feio, o que é doloroso, horroroso, nojento, que, apesar de todos os esforços, sempre torna a irromper, $m$ conformidade com a origem da natureza humana: deve assim proceder, em particular, no tocante às paixões e angustias e dores psíquicas, e no que é inevitavelmente ou insuperavelmente feio deve fazer com transpareça o significativo. Após essa grande, imensa tarefa da arte, o que se chama propriamente arte, a das obras de arte, não é mais que um apêndice: um homem que sente em si um excedente de tais forças embelezadoras, ocultadoras e reinterpretantes procurará, enfim, desafogar esse excedente em obras de arte; assim também fará, em circunstâncias especiais, todo um povo. - Mas agora iniciamos geralmente pelo final, agarramo-nos à sua cauda e pensamos que a arte das obras de arte é o verdadeiro, que a partir dela a vida deve ser melhorada e transformada - tolos que somos! Se damos início à refeição pela sobremesa e saboreamos doce após doce, não surpreende que arruinemos o estômago e até mesmo o apetite para o bom, substancial, nutritivo alimento que nos oferece a arte! (NIETZSCHE, 2008b, p.82-3).

\footnotetext{
12 A palavra continuação (Weiterentwicklung) tem sentido de desenvolvimento.
} 
Nietzsche se põe contra o que ele denomina de "arte das obras de arte", isto é, as obras concretas - a música, o poema, o romance, etc. -, pois a arte mesma possui uma função maior e mais nobre que o embelezamento mediante essas produções específicas, que nada mais seriam do que o apêndice. Ela é uma atividade exercida sobre toda a existência. O que a arte nos ensinou é a criação. Mas não qualquer criação, e esse é o ponto que nos faz remeter ao classicismo. Para manter distância de uma concepção de criação enquanto um ato miraculoso de um ser divino - o gênio -, Nietzsche introduz a criação classicista na qual a medida e o cálculo se fazem necessários para demonstrar a humanização desse processo, isto é, que ele não é derivado de inspiração. Nesse sentido, ele prioriza os elementos característicos do classicismo que são o equilíbrio, a ordem e a harmonia (Cf. ROSENFELD; GUINZBURG, 1999, p.374-5). Enquanto os demais, como o princípio de universalidade ou a desoneração do artista de sua obra - uma vez que ele é o artesão que trabalha mediante regras estabelecidas - são características pouco abordadas. Vale ressaltar o método estratégico de Nietzsche para lidar com seus temas: ele compreende que é a capacidade de ordenar, harmonizar e hierarquizar que são, no clássico, expressão de força. Em sua perspectiva, diferente da concepção romântica na qual os elementos aparecem como que por milagre ou por capacidade mística, no classicismo essa tarefa é fundamentalmente humana e precisa ser constantemente apreendida. Por isso o criar, no romantismo, era um ato muito próximo da religiosidade cristã, e assim, teológico:

\footnotetext{
Vale lembrar que a palavra criação nem sempre esteve presa a uma conotação teológica. O monopólio teológico dela é apenas um episódio ligado ao apogeu do monoteísmo e isso aconteceu na Idade Média, quando só Deus era criador. No curso da história, o termo teve outros sentidos. Quando levamos em consideração a etimologia da palavra, a proeminência do teológico desaparece. A palavra latina creare tem o sentido de engendramento está filologicamente ligada a crescere, sugerindo as noções de crescimento e de desenvolvimento. A raiz mais longínqua da palavra criação dava conta da especificidade do procreare, isto é, da procriação, o que justifica que seja aplicada a uma conduta instauradora e geradora de obras (DIAS, 2011, p.63).
}

Diferente da acepção de criar o "tudo do nada", comum ao ato romântico e cristão, esse novo entendimento sobre a criação está em consonância com o vir-a-ser que é uma marca da vida mesma. Criar torna-se palavra de ordem na filosofia de Nietzsche e é isso que excita sua concepção de estética, que deixa de ser uma ciência do belo e passa a ser pensada como atividade exercida sobre todas as coisas da vida e do real, devendo ser incorporada para o agir afirmativo. Logo, com Humano a função criativa passa a fazer parte de todas as esferas da existência: na moral, na política, na estética, no conhecimento.

A criação é uma maneira de interpretar nossas próprias vivencias atribuindo significados distintos e não esperando que tais significados já existam. Por isso desmistifica a concepção de gênio, pois ela nos faria crer que criar é restrito a um número limitado de indivíduos e, por isso mesmo, nossa própria existência seria obra de outro, no sentido de ser dominado externamente o que não faria sentido, sendo que estaríamos regredindo a uma concepção de coerção que já foi eliminada de nossa interpretação. O mais interessante é que remanejando a função da arte para as demais esferas da vida, Nietzsche não recupera o interesse apenas na vida como também recupera o interesse pela educação da sensibilidade. É isso que irá distinguir sua concepção de domínio das paixões do domínio socrático.

\section{Pedagogia das paixões? A proposta nietzschiana}

É preciso admitir que, seja em tom metafísico - como em $O$ nascimento da tragédia - ou seja em tom naturalista - como em Humano -, o corpo é objeto central na filosofia de Nietzsche, 
reconhecendo-o como um elemento bastante reprimido e subestimado na história do pensamento ocidental. Foi mérito dos antigos gregos não negarem ou buscarem reprimir as forças naturais do corpo, permitindo a elas um espaço para se manifestarem - o teatro, os ritos dionisíacos. Conforme vai se afastando daquela "nostalgia pela Grécia", comum na Alemanha de seu tempo, ele busca reinterpretar essa habilidade grega para uma aplicação mais particular, a fim de tentar sugerir uma proposta educativa para o corpo que não fosse repressora ou normativa. A realização de tal tarefa o obrigou a enfrentar diversos obstáculos, como a desconstrução da ideia de que corpo e racionalidade fossem esferas distintas, tornando-as agora parte de um só conjunto e forçando admitir que todo pensar "consciente" e "racional" nada mais é do que fruto das pulsões, das paixões e demais elementos do inconsciente ${ }^{13}$.

Em textos mais tardios, como em Crepúsculo dos Ídolos, explica a suposta "origem" da racionalidade, pelo menos, da socrática. Segundo Nietzsche, Sócrates erige a razão como um instrumento de combater a tirania dos impulsos que ameaçavam a civilização. A racionalidade aparece como "salvadora", o que reforça a diferença entre Apolo e Sócrates, já que o último acreditou na possibilidade de controlar essas forças, e sustentando um erro maior ainda, que seria possível fazê-lo em um determinando instante; como se em um determinado momento a razão pudesse ser capaz de reprimir essas forças, ignorando que elas são processos inconscientes levados à consciência através de um caminho construído historicamente. Eis a grande diferença para com a proposta pedagógica de Nietzsche, que permite a nós falar em cálculo e medida aplicada à sensibilidade - de modo muito distinto dos socráticos, que toma um conceito ou mesmo uma ideia como norma para o corpo e as paixões.

A partir de Humano, demasiado humano, Nietzsche passa a pensar a criação de si, mas não como processo instantâneo, mas sim enquanto uma formação que leva tempo e precisa ser paciente. Ele está ciente de que criar é um processo que precisa considerar que nem tudo pode ser deliberado, pois reconhece que as forças do inconsciente não pedem licença para agir. Ocorre que também reconhece - e aqui torna isso muito mais nítido do que em textos juvenis - que essas forças afetam e são afetadas pelos elementos internos e externos, isto é, vivências e experiências sociais e individuais, ou seja, a esfera do inconsciente não está à parte do espaço e tempo em que o indivíduo vive ${ }^{14}$. Criar a si mesmo como obra de arte é organizar as experiências e vivências a fim de criar um estilo para que as paixões e impulsos - das quais não temos domínio - se manifestem, se exteriorizem; mesmo porque seria absurdo não admitir algum grau de consciência. Em outras palavras, apesar de não estar em nosso poder deliberar em determinado instante sobre a possibilidade de manifestar ou não um afeto, ainda é possível uma organização das vivências e experiências a fim de orientar o caminho a ser tomado por essas pulsões. Salienta-se, no entanto, que essa organização é poética e não lógica/racional ${ }^{15}$. Dito de outro modo, criar a si mesmo a fim de educar a sensibilidade não é um processo que leva a priori conceitos, normas ou ideias; é um processo experimental que precisa ser reavaliado e trabalhado cotidianamente, devido as inúmeras falhas que ocorrem no caminho. Nietzsche não está

\footnotetext{
${ }^{13}$ Tal evidência de nosso raciocínio pode ser identificado no aforismol15 "O assim chamado Eu" de Aurora, quando admite que a nós falta linguagem para denominar os estados menos extremos das paixões. Assim, demonstra que conhecemos que é impossível conhecer o que se passa em nosso íntimo, uma vez que a consciência é uma camada, bastante superficial, do ser humano.

14 Por isso mesmo a desmedida ou a leitura exclusiva pelo viés orgiástico é tão simplória, desconsidera as inúmeras experiências sociais e individuais, julgando que alguém poderia, deliberadamente, escolher a desmedida. Inclusive, a imposição dessa norma pode ser tão repressora quanto a posição do cristianismo. Seria muita ingenuidade de Nietzsche desconsiderar esses fatores.

15 É digno de nota, no aforismo "Viver e Inventar" de Aurora, o termo traduzido por inventar foi Erdichten, e o Dichtungé o termo para se referir à atividade do poeta - ou seja, é criação poética, artística. Segundo Nietzsche, nossas vivências não possuem sentido em si só e são muito mais do que nelas se acha ou não se acha. A invenção torna-se necessária uma vez que as vivências se lançam a diferentes impulsos, sem seguir uma ordem racional. Além disso, o próprio vocábulo Erlebnis, isto é, "vivência", no alemão, designa algo que não pode ser construído ou experimentado racionalmente, mas apenas sentido (sobre isso, cf. VIESENTEINER, 2013).
} 
buscando educar os impulsos no sentido de reprimi-los, nem dizer o que deve ou não deve ser exteriorizado, pois aos impulsos e às paixões não cabem juízos de valores. Contudo, a expressão precisa ser reforçada por uma saída criada pelo próprio ser humano, sem uma norma externa instituída por religiões, políticas ou morais de diversas correntes. Nesse sentido, educar é um cuidado que cada um precisa ter com sua própria sensibilidade a fim de vencer as forças repressoras da natureza com meios artísticos.

Encaminhando o fim da discussão, é preciso reforçar que uma pedagogia das paixões não se refere à formação repressora e normativa das mesmas. Diz respeito apenas à capacidade que o indivíduo possui de criar a si mesmo, a partir de diferentes estilos, para dar vazão as forças corpóreas por meio de diferentes gostos ou predileções. A pedagogia tem mais relação com a aprendizagem de nossas experiências terrenas e como conduzir a nós mesmos sem ser escravos de normas racionais de outros, ou escravo de nossas próprias paixões. Ao tomar essa orientação, esperamos que tenha sido possível esclarecer o porquê de noções como cálculo e medida não serem estranhas. Ora, elas aparecem não no âmbito da lógica exclusivamente, mas no da estética e aplicado às paixões - não como forma de reprimir, mas moldar a partir de um exercício individual. Também por isso se pode dizer que Nietzsche não destrói a razão, mas reconstrói a ordem hierárquica existente entre ela e o corpo, tornando a racionalidade submissa às forças corpóreas, mas sem distinguir como dois elementos diferentes. Na filosofia nietzschiana, o racionalizar é estético e o corpo é pensante. paixões como questão. Griot : Revista de Filosofia, Amargosa - BA, v.20, n.2, p.174-189, junho, 2020. 


\section{Referências}

DIAS, R. Nietzsche, vida como obra de arte. Rio de Janeiro: Civilização Brasileira, 2011 a. (Coleção contemporânea: Filosofia, literatura e artes).

HALES, S. Nietzsche onlogic. Philosophy and Phenomenological Research, vol. 56, n. 4, p. 819835, 1996.

LEBRUN, G. Quem era Dioniso In: LEBRUN, G. A filosofia e sua história. São Paulo: Cosac \& Naify, 2006.

NASSER, E. O romantismo em Nietzsche enquanto um problema temporal, estético e ético. Revista Trágica, vol.2, n.2, p.31-46, 2009.

NIETZSCHE, F. Ecce homo. Tradução, notas e posfácio de Paulo Cesar de Souza. São Paulo: Cia de bolsa, 2008a.

NIETZSCHE, F. Humano, demasiado humano I. Tradução de Paulo Cesar de Souza. São Paulo: Cia das Letras, 2004.

NIETZSCHE, F. Humano, demasiado humano II. Tradução de Paulo Cesar de Souza. São Paulo: Cia das Letras, 2008b.

NIETZSCHE, F. O nascimento da tragédia. $2^{\text {a }}$ ed. Tradução de J. Guinsburg. São Paulo: Cia das Letras, 2005.

NIETZSCHE, F. O crepúsculo dos ídolos. Tradução de Paulo Cesar de Souza. São Paulo: Cia das Letras, 2010.

PAPPAS, N. Nietzsche's Apollo. Journal of Nietzsche studies, Pennsylvania, vol.45, n.1 (Spring), p.43-53.

RODRIGUES, L. G. Nietzsche e os gregos: arte e mal-estar na cultura. São Paulo: Annablume, 2003.

ROSENFELD, A.; GUINZBURG, J. Apêndice In: GUINZBURG, J. O classicismo. São Paulo: Perspectiva, 1999.

SCHACHT, R. Nietzsche. New York: Routledge, 2002. (The Argument of Philosophers).

VIESENTEINER, J. L. O conceito de vivência (Erleibnis) em Nietzsche: gênese, significação e recepção. Kriterion, n.127, p.141-155, 2013.

Autor(a) para correspondência: Paulo Cesar Jakimiu Sabino, Rua Dr. Faivre, 405 - $6^{\circ}$ andar - Ed. D. Pedro II, 80060-140, Curitiba - PR, Brasil.pcjsabino1@yahoo.com.br 